\title{
PENENTUAN KAPASITAS JALAN DUA LAJUR DUA ARAH TIDAK TERBAGI DENGAN METODE MKJI, KONSEP PKJI, DAN SURVEI
}

\author{
Louis Lowenta ${ }^{1}$ dan $_{\text {Najid }}^{2}$ \\ ${ }^{1}$ Program Studi Sarjana Teknik Sipil, Universitas Tarumanagara, Jl. Letjen S. Parman No.1 Jakarta \\ Email: Jlowenta@gmail.com \\ ${ }^{2}$ Program Studi Sarjana Teknik Sipil, Universitas Tarumanagara, Jl. Letjen S. Parman No.1 Jakarta \\ Email:najid@ft.untar.ac.id
}

\begin{abstract}
ABSTRAK
Kapasitas jalan merupakan kemampuan suatu ruas jalan untuk dapat menampung arus atau volume lalu lintas yang terjadi dalam waktu satu jam (kend/jam). Dalam penelitian ini diambil 3 buah sample jalan yaitu Jalan Meruya Selatan, Jalan Sacna, Sunter, dan Jalan Kebon Pedes, Bogor yang akan dijadikan sebagai wilayah studi untuk mendapatkan nilai kapasitas pada jalan tersebut, sehingga nilai kapasitas tersebut dapat dibandingkan dengan nilai kapasitas dari MKJI yang selama ini menjadi acuan. Digunakan 3 buah jalan yaitu untuk melakukan 2 buah perbandingan yaitu dengan 2 jalan di Jakarta untuk membandingkan faktor dari hambatan samping sedangkan jalan antara di Jakarta dan Bogor untuk membandingkan faktor ukuran kota. MKJI itu sendiri sudah dijadikan sebagai acuan dan sudah dibuat sejak dibuat pada 1997, karena dianggap sudah tidak relevan dengan keadaan saat ini dan sudah sangat lama maka muncullah konsep PKJI yang diharapkan dapat dijadikan sebagai acuan yang baru untuk menggantikan MKJI yang sudah lama. Hasil dari penelitian ini adalah untuk jalan dua lajur dua arah tidak terbagi dengan hambatan samping sangat tinggi, hasil dari nilai kapasitas yang diperoleh ternyata melewati hasil rencana dari MKJI sedangkan untuk jalan dengan hambatan samping sedang maka hasil kapasitas masih belum melewati MKJI. Dari hasil tersebut dapat dikatakan bahwa MKJI perlu diadakan pengkajian ulang.
\end{abstract}

Kata kunci: Kapasitas Jalan, MKJI, Konsep PKJI,

\section{PENDAHULUAN}

\section{Latar Belakang}

Kapasitas jalan merupakan kemampuan dari suatu jalan untuk bisa menampung volume lalu lintas dalam suatu waktu tertentu. Ketika arus rendah maka kecepatan dari kendaraan yang melintas tidak akan mengalami gangguan dari kendaraan lain, semakin banyak kendaraan yang melewati suatu jalan tersebut, maka kecepatan akan semakin turun dan melambat sampai suatu saat volume lalu lintas tidak bisa lagi bertambah, di sinilah kapasitas terjadi. Setelah itu arus akan berkurang terus dalam kondisi arus yang dipaksakan sampai suatu saat kondisi macet total, arus tidak bergerak dan kepadatan tinggi. Salah satu penyebab padatnya kapasitas jalan adalah karena pertumbuhan jumlah penduduk yang semakin meningkat tiap tahunnya, sehingga memicu terjadinya pertambahan kendaraan bermotor. Pada suatu daerah yang jumlah penduduknya padat maka akan diimbangi dengan penggunaan kendaraan bermotor yang banyak pula. Hal ini berakibat pada meningkatnya volume kendaraan pada suatu daerah. Meningkatnya volume kendaraan menyebabkan kapasitas jalan yang tersedia tidak cukup, akibatnya terjadilah kemacetan.Kemacetan lalu lintas terjadi akibat volume lalu lintas hampir mendekati kapasitas jalan yang tersedia. Penyebab lain dari padatnya kapasitas pada suatu jalan adalah karena hambatan samping. Hambatan samping merupakan salah satu hal yang paling berpengaruh terhadap penuhnya kapasitas suatu jalan. Tingginya aktivitas di samping jalan sangat berpengaruh terhadap kapasitas dan kinerja jalan pada suatu wilayah perkotaan. Diantaranya seperti PKL, pejalan kaki, penyebrang jalan, kendaraan yang berhenti sembarangan (angkutan kota, bus dalam kota), kendaraan yang parkir di bahu jalan, kendaraan yang berjalan lambat (becak, sepeda), dan kendaraan yang keluar masuk pada aktivitas guna lahan sisi jalan.Tujuan dalam penelitian ini antara lain adalah untuk menganalisis perhitungan kapasitas jalan dengan metode MKJI, PKJI, dan mendapatkan model dari hasil survei, kemudian membandingkan nilai kapasitas jalan 2 lajur 2 arah tak terbagi antara jalan di Jakarta dan di Bogor dari hasil survei dengan hasil perhitungan dengan metode MKJI.

\section{Kapasitas Jalan}

Menurut (MKJI 1997), kapasitas jalan adalah arus maksimum melalui suatu titik di jalan yang dapat dipertahankan per satuan jam pada kondisi tertentu. Menurut Peraturan Menteri Perhubungan No: KM 14 Tahun 2006, "Kapasitas jalan adalah kemampuan ruas jalan untuk menampung volume lalu lintas ideal per satuan waktu, dinyatakan dalam 
kendaraan/jam atau satuan mobil penumpang (smp)/jam." Faktor-faktor yang mempengaruhi kapasitas jalan antara lain:

1. Kondisi Geometri

2. Kondisi Lalu Lintas

3. Kondisi Lingkungan

Persamaan dasar untuk menentukan kapasitas adalah sebagai berikut :

$\mathrm{C}=\mathrm{Co} \times \mathrm{FCw} \times \mathrm{FCsp} \times \mathrm{FCsf} \times \mathrm{FCcs}$

Dengan :

$\mathrm{C} \quad=$ Kapasitas $(\mathrm{smp} / \mathrm{jam})$

Co $\quad=$ Kapasitas dasar (smp/jam)

$\mathrm{FCw} \quad=$ Faktor penyesuaian lebar jalan

FCsp = Faktor penyesuaian pemisahan arah (hanya untuk jalan tak terbagi)

FCsf = Faktor penyesuaian hambatan samping dan bahu jalan/kereb

FCcs $\quad=$ Faktor penyesuaian ukuran kota

Menurut PKJI Kapasitas didefinisikan sebagai arus maksimum yang dapat dipertahankan per satuan jam yang melewati suatu segmen jalan dalam kondisi yang ada. Untuk jalan 2/2TT, kapasitas didefinisikan untuk arus dua arah, tetapi untuk jalan dengan banyak lajur, arus dipisahkan per arah perjalanan dan kapasitas didefinisikan per lajur. Karakteristik utama segmen jalan yang mempengaruhi kapasitas jalan ada lima, yaitu geometrik jalan, komposisi arus lalu lintas dan pemisah arah, pengaturan lalu lintas, aktivitas samping jalan, dan perilaku pengemudi. Kapasitas segmen dapat dihitung menggunakan persamaan di bawah.

$\mathrm{C}=\mathrm{C}_{0} \times \mathrm{FC}_{\mathrm{LJ}} \times \mathrm{FC}_{\mathrm{PA}} \times \mathrm{FC}_{\mathrm{HS}} \times \mathrm{FC}_{\mathrm{Uk}}$

Dengan :

$\mathrm{C} \quad=$ Kapasitas (skr/jam)

Co $\quad=$ Kapasitas dasar (skr/jam)

$\mathrm{FC}_{\mathrm{LJ}} \quad=$ Faktor penyesuaian kapasitas terkait lebar jalur atau jalur lalu lintas

$\mathrm{FC}_{\mathrm{PA}}=$ Faktor penyesuaian kapasitas terkait pemisahan arah, hanya pada jalan tak terbagi

$\mathrm{FC}_{\mathrm{HS}} \quad=$ Faktor penyesuaian kapasitas terkait KHS pada jalan berbahu atau berkereb

$\mathrm{FC}_{\mathrm{UK}} \quad=$ Faktor penyesuaian kapasitas terkait ukuran kota

\section{Hambatan Samping}

Menurut MKJI Hambatan samping yaitu aktivitas samping jalan yang dapat menimbulkan konflik dan berpengaruh terhadap pergerakan arus lalu lintas serta menurunkan fungsi kinerja jalan. Tipe hambatan samping terbagi menjadi:

1. Pejalan kaki

2. Kendaraan berhenti atau parkir

3. Kendaraan yang masuk dan keluar dari lahan samping jalan

4. Kendaraan lambat (MKJI,1997)

Tingkatan hambatan samping dikelompokan menjadi lima kelas, yaitu dari kelas sangat rendah sampai kelas sangat tinggi sebagai fungsi dan kejadian hambatan samping disepanjang jalan yang diamati dalam satu jam. Untuk lebih jelasnya dapat dilihat pada faktor penentuan hambatan samping dalam menentukan suatu tingkat pelayanan jalan raya dapat dibaca pada Tabel 1.

Faktor-faktor yang mempengaruhi nilai kelas hambatan samping dengan frekuensi bobot kejadian per $200 \mathrm{~m}$ dari segmen jalan yang diamati ppada kedua sisi jalan, seperti yang dijelaskan pada Tabel 2.

Menurut PKJI Hambatan samping adalah kegiatan di samping segmen jalan yang berpengaruh terhadap kinerja lalu lintas (PKJI 2014). Hambatan samping ini terbagi menjadi 4 kategori berbeda dengan bobot yang berbeda seperti pada Tabel 3.

Tingkatan hambatan samping setelah dikalikan dengan bobot diatas dibagi menjadi lima kelas. Kelas tersebut akan mempengaruhi kapasitas jalan dan juga akan mempengaruhi kecepatan arus bebas suatu jalan. Pada Tabel 4 akan menunjukan kelas-kelas hambatan samping. 
Tabel 1. Nilai kelas hambatan samping (sumber:MKJI 1997)

\begin{tabular}{cccc}
\hline $\begin{array}{c}\text { Kelas Hambatan Samping } \\
\text { (SCF) }\end{array}$ & Kode & $\begin{array}{c}\text { Jumlah kejadian per } \\
\text { 200m per jam }\end{array}$ & \multicolumn{1}{c}{ Kondisi daerah } \\
\hline $\begin{array}{c}\text { Sangat Rendah } \\
\text { Rendah }\end{array}$ & VL & $<100$ & $\begin{array}{l}\text { Daerah pemukiman; hampir tidak ada kegitan } \\
\text { Daerah pemukiman; berupa angkutan umum }\end{array}$ \\
Sedang & M & $300-299$ & $\begin{array}{l}\text { dan sebagainya } \\
\text { Tinggi }\end{array}$ \\
Sangat tinggi & H & $500-499$ & $\begin{array}{l}\text { Daerah industri; beberapa toko di sisi jalan } \\
\text { Dangat tinggi } \\
\text { Daersial; aktivitas sisi jalan yang } \\
\text { jalan }\end{array}$ \\
\hline
\end{tabular}

Tabel 2. Penentuan tipe frekuesi kejadian hambatan samping. (Sumber:MKJI 1997)

\begin{tabular}{lcc}
\hline Tipe kejadian hambatan samping & Simbol & Faktor bobot \\
\hline Pejalan kaki & PED & 0.5 \\
Kendaraan parker & PSV & 1.0 \\
Kendaraan masuk dan keluar sisi jalan & EEV & 0.7 \\
Kendaran lambat & SMV & 0.4 \\
\hline
\end{tabular}

Tabel 3. Pembobotan Hambatan Samping (Sumber:PKJI 2014) Jenis hambatan samping

Faktor bobot

\begin{tabular}{lc}
\hline Pejalan kaki di badan jalan dan yang menyebrang & 0.5 \\
Kendaraan umum dan kendaraan lainnya yang berhenti & 1.0 \\
Kendaraan keluar/masuk sisi atau lahan samping jalan & 0.7 \\
Arus kendaraan lambat (kendaraan tak bermotor) & 0.4 \\
\hline
\end{tabular}

Tabel 4. Kriteria Kelas Hambatan Samping (sumber:PKJI 2014)

\begin{tabular}{|c|c|c|c|}
\hline Kelas Hambatan Samping & Kode & $\begin{array}{l}\text { Jumlah kejadian per } \\
200 \mathrm{~m} \text { per jam }\end{array}$ & Kondisi daerah \\
\hline Sangat Rendah & SR & $<100$ & Daerah pemukiman, tersedia jalan lingkungan \\
\hline Rendah & $\mathrm{R}$ & $100-299$ & $\begin{array}{l}\text { Daerah pemukiman, ada beberapa angkutan } \\
\text { umum }\end{array}$ \\
\hline Sedang & $S$ & $300-499$ & $\begin{array}{l}\text { Daerah industry, ada beberapa toko di } \\
\text { sepanjang sisi jalan }\end{array}$ \\
\hline Tinggi & $\mathrm{T}$ & $500-899$ & $\begin{array}{l}\text { Daerah komersial, ada aktivitas sisi jalan yang } \\
\text { tinggi }\end{array}$ \\
\hline Sangat tinggi & ST & $>900$ & Daerah komersial; ada aktivitas pasar sisi jalan \\
\hline
\end{tabular}

\section{Kecepatan Arus Bebas}

Menurut MKJI 1997, kecepatan arus bebas (FV) didefinisikan sebagai kecepatan paada tingkat arus nol, yaitu kecepatan yang akan dipilih pengemudi jika mengendarai kendaraan bermotor tanpa dipengaruhi oleh kendaraan bermotor lain di jalan. Kecepatan arus bebas dapat dihitung dengan persamaan matematis yang terdapat pada MKJI (1997) dengan mempertimbangkan data geometrik serta kondisi lingkungan jalan. Untuk menghitung kecepatan arus bebas.

Persamaan yang digunakan adalah sebagai berikut:

$$
\mathrm{FV}=(\mathrm{FVo}+\mathrm{FVw}) \times \mathrm{FFV} s \mathrm{x} \text { FFVes. }
$$

Dengan :

$\overline{\mathrm{FV}}=$ Kecepatan arus bebas untuk kendaraan ringan dalam kondisi aktual

FVo = kecepatan dasar arus bebas untuk kendaraan ringan $(\mathrm{km} / \mathrm{jam})$

$\mathrm{FVw}=$ faktor penyesuaian kecepatan untuk lebar jalan $(\mathrm{km} / \mathrm{jam})$

FFVsf = faktor penyesuaian untuk hambatan samping dan bahu atau kereb jalan

$\mathrm{FFV} c \mathrm{~s}$ = faktor penyesuaian kecepatan untuk ukuran kota 
Menurut PKJI kecepatan arus bebas (VB) untuk jenis kendaraan ringan ditetapkan sebagai kriteria dasar untuk kinerja segmen jalan, nilai VB untuk KB dan SM ditetapkan hanya sebagai referensi. VB untuk KR berkisar anatara 10-15\% lebih besar dari jenis kendaraan lain. VB dihitung menggunakan persamaan sebagai berikut :

$$
V_{B}=\left(V_{B D}+V_{B L}\right) \times F V_{B H S} \times F V_{B U K}
$$

Dengan:

$V_{B} \quad=$ Kecepatan arus bebas untuk kendaraan ringan dalam kondisi aktual

$V_{B D} \quad=$ kecepatan dasar arus bebas untuk kendaraan ringan $(\mathrm{km} / \mathrm{jam})$

$V_{B L} \quad=$ faktor penyesuaian kecepatan untuk lebar jalan $(\mathrm{km} / \mathrm{jam})$

$F V_{B H S}=$ faktor penyesuaian untuk hambatan samping dan bahu atau kereb jalan

$F V_{B U K}=$ faktor penyesuaian kecepatan untuk ukuran kota

\section{METODOLOGI PENELITIAN}

Sistematika proses penelitian merupakan tahappan penelitian yang harus dilakukan secara beruntun agar tujuan penelitian dapat dicapai sesuai yang diharapkan. Tahapan ppenelitian yang harus dilakukan adalah sebagai berikut:

Tahap I : Menentukan tujuan penelitian, tinjauan pustaka dan metodologi penelitian

Tahap II : : Melakukan survei awal dan membuat formulir survei

Tahap III : Melakukan pengumpulan data dengan survei

Tahap IV : Melakukan analisis data

Tahap V : Melakukan analisis data survei kapasitas menurut MKJI dan PKJI

Tahap VI : : Melakukan perbandingan analisis menurut MKJI, PKJI dan hasil survei

Tahap VII : Kesimpulan dan saran

\section{Kompilasi data}

Data-data yang didapat terdiri dari:

1. Volume lalu lintas

2. Kecepatan lalu lintas

3. hambatan samping

\section{ANALISIS DATA}

Pada analisis ini akan dilakukan analisis mengenai volume lalu lintas, kecepatan lalu lintas, kapasitas, kecepatan arus bebas dan hambatan samping.Dari hasil analisis yang akan didapatkan kemudian akan dibandingkan berdasarkan perbedaan hambatan samping dan perbedaan ukuran kota.

\section{Volume Lalu-Lintas}

Volume lalu lintas Jalan Meruya Selatan pada hari kamis dengan tipe jalan adalah dua lajur dua arah tak terbagi (2/2 UD), arus lalu lintas dua arah $\geq 1800$ (kend/jam) dan lebar jalur 6 m, maka Heavy Vehicle (HV) dikalikan 1.2 dan Motorcycle (MC) dikalikan 0.25. Volume lalu lintas pada Jalan Meruya Selatan di pagi hari dapat dilihat pada Tabel 5 
Tabel 5. Volume Lalu Lintas Jalan Meruya Selatan

\begin{tabular}{|c|c|c|c|c|}
\hline $\begin{array}{l}\text { Jalan } \\
\text { Waktu } \\
\text { Tata Guna Lahan Kiri } \\
\text { Tata Guna Lahan Kanan } \\
\text { Hari }\end{array}$ & $\begin{array}{l}\text { :Jalan Meruya S } \\
: \\
: \text { Kampus } \\
: \text { Tempat makan } \\
: \text { Kamis }\end{array}$ & & & \\
\hline \multirow[t]{2}{*}{ Jam } & \multicolumn{3}{|c|}{$\begin{array}{c}\text { Volume Lalu Lintas } \\
\text { (kend/jam) }\end{array}$} & \multirow[t]{2}{*}{$\begin{array}{c}\mathrm{Q} \text { (Volume Lalu Lintas) } \\
\text { (smp/jam) }\end{array}$} \\
\hline & Sepeda Motor & Mobil & Truk/ Bus & \\
\hline $06.00-07.00$ & 3560 & 399 & 0 & 1289 \\
\hline $06.15-07.15$ & 4159 & 426 & 0 & 1465,75 \\
\hline $06.30-07.30$ & 4668 & 445 & 0 & 1612 \\
\hline $06.45-07.45$ & 5019 & 466 & 0 & 1620,75 \\
\hline $07.00-08.00$ & 4810 & 458 & 0 & 1660,5 \\
\hline $11.00-12.00$ & 3460 & 670 & 1 & 1536,2 \\
\hline $11.15-12.15$ & 3828 & 676 & 1 & 1634,2 \\
\hline $11.30-12.30$ & 3961 & 620 & 1 & 1611,45 \\
\hline $11.45-12.45$ & 3873 & 594 & 0 & 1562,25 \\
\hline $12.00-13.00$ & 3536 & 611 & 1 & 1496,2 \\
\hline $17.00-18.00$ & 3719 & 540 & 1 & 1520,95 \\
\hline $17.15-18.15$ & 3892 & 582 & 1 & 1556,2 \\
\hline $17.30-18.30$ & 3247 & 624 & 0 & 1435,75 \\
\hline $17.45-18.45$ & 2895 & 643 & 0 & 1366,75 \\
\hline $18.00-19.00$ & 2665 & 640 & 0 & 1306,25 \\
\hline
\end{tabular}

\section{Klasifikasi Hambatan Samping}

Data Hambatan samping yang diperoleh pada jalan yang telah di survei terdapat beberapa perbedaan. Perbedaan yang ada pada hambatan samping akan berpengaruh pada perhitungan kapasitas dan kecepatan arus bebas. Data hambatan samping dalam satu jam pada Jalan Meruya Selatan yang sudah dikalikan dengan koefisiennya dapat dilihat pada Tabel 6

Tabel 6. Nilai Hambatan Samping Jalan Meruya Selatan

\begin{tabular}{|c|c|c|c|}
\hline Jalan & Jalan Meruya Selatan & & \\
\hline Tata Guna Lahan Kiri & Kampus & & \\
\hline \multirow{2}{*}{ Tata Guna Lahan Kanan } & Tempat Makan & & \\
\hline & MKJI & PKJI & Klasifikasi \\
\hline $06.00-07.00$ & 918,7 & 918,7 & VH \\
\hline $06.15-07.15$ & 907,3 & 907,3 & $\mathrm{VH}$ \\
\hline $06.30-07.30$ & 1349 & 1349 & VH \\
\hline $06.45-07.45$ & 1731,4 & 1731,4 & VH \\
\hline $07.00-08.00$ & 1982,8 & 1982,8 & VH \\
\hline $11.00-12.00$ & 969,7 & 969,7 & $\mathrm{VH}$ \\
\hline $11.15-12.15$ & 920 & 920 & VH \\
\hline $11.30-12.30$ & 970,7 & 970,7 & $\mathrm{VH}$ \\
\hline $11.45-12.45$ & 984,8 & 984,8 & $\mathrm{VH}$ \\
\hline $12.00-13.00$ & 942,1 & 942,1 & $\mathrm{VH}$ \\
\hline $17.00-18.00$ & 1863,1 & 1863,1 & $\mathrm{VH}$ \\
\hline $17.15-18.15$ & 1544,7 & 1544,7 & VH \\
\hline $17.30-18.30$ & 1284,2 & 1284,2 & $\mathrm{VH}$ \\
\hline $17.45-18.45$ & 1028,8 & 1028,8 & $\mathrm{VH}$ \\
\hline $18.00-19.00$ & 933,6 & 933,6 & VH \\
\hline
\end{tabular}

\section{Kecepatan Arus Bebas}

Tipe Jalan Meruya Selatan adalah dua lajur dua arah tidak terbagi (2/2UD) dengan lebar lajur $3.00 \mathrm{~m}$ dan lebar kerb $1.00 \mathrm{~m}$ dan memiliki 10.374.200 penduduk. Hasil perhitungan kecepatan arus bebas untuk Jalan Meruya Selatan pada hari kamis dapat dilihat pada Tabel 7 
Tabel 7. Kecepatan Arus Bebas Jalan Meruya Selatan (Sumber: MKJI dan hasil analisis data)

\begin{tabular}{ccccccc}
\hline \multicolumn{7}{c}{ Kecepatan Arus Bebas } \\
\hline Jam & Fvo & FVw & Fvo + FVw & FFVsf & FFVcs & FV \\
\hline $06.00-07.00$ & 42 & -3 & 39 & 0.72 & 1.03 & 28.92 \\
$06.15-07.15$ & 42 & -3 & 39 & 0.72 & 1.03 & 28.92 \\
$06.30-07.30$ & 42 & -3 & 39 & 0.72 & 1.03 & 28.92 \\
$06.45-07.45$ & 42 & -3 & 39 & 0.72 & 1.03 & 28.92 \\
$07.00-08.00$ & 42 & -3 & 39 & 0.72 & 1.03 & 28.92 \\
$11.00-12.00$ & 42 & -3 & 39 & 0.72 & 1.03 & 28.92 \\
$11.15-12.15$ & 42 & -3 & 39 & 0.72 & 1.03 & 28.92 \\
$11.30-12.30$ & 42 & -3 & 39 & 0.72 & 1.03 & 28.92 \\
$11.45-12.45$ & 42 & -3 & 39 & 0.72 & 1.03 & 28.92 \\
$12.00-13.00$ & 42 & -3 & 39 & 0.72 & 1.03 & 28.92 \\
$17.00-18.00$ & 42 & -3 & 39 & 0.72 & 1.03 & 28.92 \\
$17.15-18.15$ & 42 & -3 & 39 & 0.72 & 1.03 & 28.92 \\
$17.30-18.30$ & 42 & -3 & 39 & 0.72 & 1.03 & 28.92 \\
$17.45-18.45$ & 42 & -3 & 39 & 0.72 & 1.03 & 28.92 \\
$18.00-19.00$ & 42 & -3 & 39 & 0.72 & 1.03 & 28.92 \\
\hline
\end{tabular}

\section{Derajat Kejenuhan (Q/C) dan Kepadatan Lalu Lintas (D)}

Derajat kejenuhan didapat dengan membagi volume lalu lintas dengan kapasitas jalan (Q/C), sedangkan kepadatan lalu lintas diperoleh dengan membagi volume lalu lintas dengan kecepatan rata-rata (Q/Vrata-rata).

Performa dan kepadatan lalu lintas pada semua jalan raya dapat dilihat pada tabel 8

Tabel 8. Performa dan Kepadatan Lalu Lintas Jalan Meruya Selatan

\begin{tabular}{|c|c|c|c|c|c|c|}
\hline \multicolumn{2}{|c|}{$\begin{array}{l}\text { Jalan } \\
\text { Tata Guna Lahan Kiri } \\
\text { Tata Guna Lahan Kanan }\end{array}$} & $\begin{array}{l}\text { Jalan Meruya Selatan } \\
\text { : Kampus } \\
\text { : Tempat Makan }\end{array}$ & \multirow[b]{2}{*}{$\begin{array}{c}\text { V rata- } \\
\text { rata }\end{array}$} & \multirow[b]{2}{*}{ FV } & \multirow[b]{2}{*}{$\mathrm{Q} / \mathrm{C}$} & \multirow[b]{2}{*}{$\mathrm{D}$} \\
\hline Jam & $\mathrm{C}$ & Q & & & & \\
\hline $06.00-07.00$ & 1662.52 & 1289 & 29 & 28.92 & 0.775 & 44.45 \\
\hline $06.15-07.15$ & 1662.52 & 1465.75 & 26.41 & 28.92 & 0.882 & 55.50 \\
\hline $06.30-07.30$ & 1662.52 & 1612 & 25.25 & 28.92 & 0.969 & 63.84 \\
\hline $06.45-07.45$ & 1662.52 & 1620.75 & 24.71 & 28.92 & 0.975 & 69.64 \\
\hline $07.00-08.00$ & 1662.52 & 1660.5 & 23.72 & 28.92 & 0.998 & 70.00 \\
\hline $11.00-12.00$ & 1889.22 & 1536.2 & 25.55 & 28.92 & 0.813 & 60.13 \\
\hline $11.15-12.15$ & 1889.22 & 1634.2 & 253 & 28.92 & 0.865 & 64.59 \\
\hline $11.30-12.30$ & 1889.22 & 1611.45 & 21.16 & 28.92 & 0.853 & 76.16 \\
\hline $11.45-12.45$ & 1889.22 & 1562.25 & 25.62 & 28.92 & 0.827 & 60.98 \\
\hline $12.00-13.00$ & 1889.22 & 1496.2 & 21.32 & 28.92 & 0.792 & 70.18 \\
\hline $17.00-18.00$ & 1662.52 & 1520.95 & 12.54 & 28.92 & 0.915 & 137.24 \\
\hline $17.15-18.15$ & 1662.52 & 1556.2 & 14.45 & 28.92 & 0.936 & 107.70 \\
\hline $17.30-18.30$ & 1662.52 & 1435.75 & 18.11 & 28.92 & 0.864 & 79.28 \\
\hline $17.45-18.45$ & 1662.52 & 1366,75 & 20,95 & 28.92 & 0.822 & 65,24 \\
\hline $18.00-19.00$ & 1662.52 & 1306,25 & 22,89 & 28.92 & 0.786 & 57,07 \\
\hline
\end{tabular}




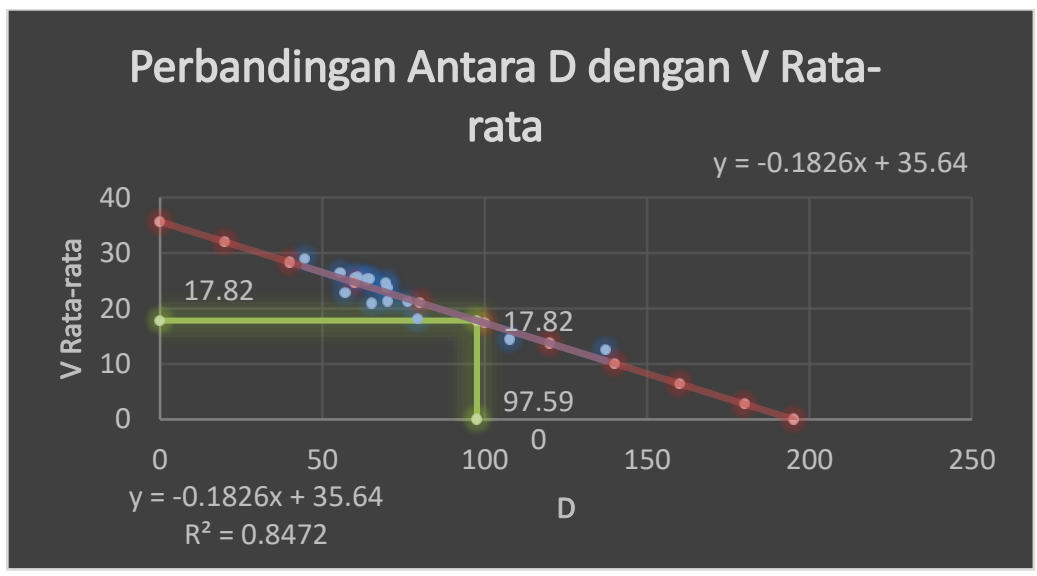

Gambar 1. Perbandingan Antara D dengan V Rata-rata

Dari Grafik diatas didapatkan persamaan $y=-0,1826 x+35,64$

Dari persamaan y diatas maka didapatkan kapasitas untuk Jalan Meruya Selatan menurut hasil survei yaitu sebesar 1739.06

\section{KESIMPULAN}

Berdasarkan hasil penelitian, dapat ditarik kesimpulan sebagai berikut:

1. Nilai dari kapasitas jalan untuk dua lajur dua arah tidak terbagi dengan faktor ukuran kota sebagai pembanding maka didapat nilai kapasitas untuk Jalan Sacna, Sunter yaitu 1349.66 kend/jam (Jakarta dengan ukuran kota 10 juta) dan untuk Jalan Kebon Pedes yaitu 1258.96 kend/jam (Bogor dengan ukuran kota 1 juta). Sedangkan untuk hambatan samping sebagai pembanding maka didapat kapasitas untuk Jalan Meruya Selatan yaitu 1739.06 (hambatan samping tinggi) dan untuk Jalan Sacna, Sunter yaitu 1349.66 (hambatan samping rendah).

2. Pada jalan dua lajur dua arah tidak terbagi, nilai FCcs survei (1.28) lebih besar dibandingkan nilai FCcs MKJI (1.22).

3. Pada jalan dua lajur dua arah tidak terbagi, nilai FCsf survei $(1,289)$ lebih besar dibandingkan dengan nilai FCsf MKJI (0.818)

4. Menurut hasil analisis pada jalan dua lajur dua arah tidak terbagi, model Greenshield dapat dimodelkan untuk mengetahui kapasitas jalan menurut survey karena nilai koefisien determinasinya $\left(\mathrm{R}^{2}\right)$ hamper mencapai

5. Pada jalan dua lajur dua arah tak terbagi, MKJI dan PKJI memiliki kesamaan pada nilai-nilai dari setiap faktor yang digunakan untuk melakukan perhitungan kapasitas jalan dan juga kecepatan arus bebas. Selain itu, rumusrumus yang digunakan pun sama dalam perhitungan kapasitas jalan dan juga kecepatan arus bebas. Namun hanya ada sedikit perbedaan saja antara MKJI dan PKJI ini yaitu perbedaan pada variabel variabel dari setiap faktor. Ada juga perbedaan pada jenis kendaraan, pada MKJI hanya ada 3 jenis kendaraan sedangkan pada PKJI terdapat 4 jenis kendaraan. Selain itu pada PKJI untuk jalan empat lajur dua arah tidak terbagi tidak dibahas lebih lanjut

\section{DAFTAR PUSTAKA}

Direktorat Jenderal Bina Jalan Kota. (1997). Manual Kapasitas Jalan Indonesia (MKJI). Jakarta.

Direktorat Jenderal Bina Marga. (2014). Pedoman Kapasitas Jalan Indonesia (PKJI).

Lalenoh, R.H. (2015). Analisa Kapasitas Ruas Jalan Sam Ratulangi Dengan Metode MKJI 1997 dan

PKJI 2014. Fakultas Teknik Jurusan Sipil Universitas Sam Ratulangi Manado. Manado.

Najid. (2015). Evaluasi Penentuan Kapasitas Jalan Berdasarkan Metode MKJI. FT. Teknik Sipil Universitas

Tarumanagara. Jakarta.

Najid. (2016). Evaluasi dan Penentuan Nilai Satuan Mobil Penumpang Pada Manual Kapasitas Jalan Indonesia. FT.

Teknik Sipil Universitas Tarumanagara. Jakarta. 
